Cahiers du MONDE RUSSE

\section{Cahiers du monde russe}

Russie - Empire russe - Union soviétique et États indépendants

40/1-2 | 1999

Archives et nouvelles sources de l'histoire soviétique, une réévaluation

\title{
Declassified materials from CPSU Central Committee plenums
}

\section{Mark Kramer}

\section{(2) OpenEdition \\ Journals}

\section{Electronic version}

URL: http://journals.openedition.org/monderusse/14

DOI: 10.4000/monderusse. 14

ISSN: $1777-5388$

\section{Publisher}

Éditions de l'EHESS

\section{Printed version}

Date of publication: 1 January 1999

Number of pages: 271-306

ISBN: 2-7132-1314-2

ISSN: $1252-6576$

Electronic reference

Mark Kramer, «Declassified materials from CPSU Central Committee plenums », Cahiers du monde russe [Online], 40/1-2| 1999, Online since 15 January 2007, Connection on 01 May 2019. URL : http:// journals.openedition.org/monderusse/14 ; DOI : 10.4000/monderusse.14 


\title{
DECLASSIFIED MATERIALS FROM CPSU CENTRAL COMMITTEE PLENUMS
}

\author{
Sources, context, highlights
}

IN October 1995 the Center for Preservation of Contemporary Documentation (TsKhSD) in Moscow, which houses the former archive of the Central Committee (CC) of the Soviet Communist Party (CPSU), received materials from the Russian Presidential Archive for a newly opened section known as fond 2. The new fond (an archival term roughly translated in English as "collection") includes different versions of CPSU Central Committee plenum transcripts from 1918 to 1990 as well as secret documents that were used at the plenums. Some 845 voluminous files (dela) of declassified plenum materials from 1918 to 1941 had been available since the early 1990s at another repository in Moscow, the former Central Party Archive (now known as the Russian Center for Preservation and Study of Documents of Recent History, or RTsKhIDNI); but the newly-opened fond 2 at TsKhSD is many times larger and much more comprehensive. ${ }^{1}$ Not only does fond 2 add to the RTsKhIDNI collection of pre-1941 materials; it also provides full documentary coverage for the dozens of Central Committee plenums after 1941.

This article will briefly discuss the structure of fond 2, the problems that arise when using the documents, and a few highlights from plenary sessions held in the 1950 s and 1960s.

1. The materials at RTsKhIDNI for Central Committee plenums from 1918 to 1941 are stored in opis' 2 of fond 17. Unlike at TsKhSD, the items at RTsKhIDNI do not constitute a separate fond. 


\section{Structure of fond 2}

Fond 2 of TsKhSD is divided among five opisi (roughly translated as "inventories" or, in this context, "record groups"). ${ }^{2}$ Initially, only opis' 1 of fond 2 was released. In early 1996 the Russian government's "Commission on Declassification of Documents Created by the CPSU" announced that the other four opisi of fond 2 had been declassified in 1995 and would be transferred to TsKhSD. ${ }^{3}$ Unfortunately, this announcement turned out to be misleading. As of mid-1998, none of the other four opisi had yet been transferred from the Presidential Archive. Thus, even though opisi 2, 3, 4, and 5 were nominally "declassified," researchers had no access to them. In response to complaints from visiting scholars, the director of TsKhSD conceded that the commission's announcement had been "premature." 4

The four additional opisi of fond 2 are due to be transferred to TsKhSD by the latter half of 1999. However, officials at TsKhSD have no direct say in the Presidential Archive's actions and therefore can offer no guarantees. Once the transfer is completed, these new opisi will provide an invaluable complement to the existing opis' 1. Opis' 2 includes the protocols and stenograms from Central Committee plenums held between 1918 and 1966, adding to the RTsKhIDNI materials. Opis' 3 includes documents from Central Committee plenums ranging from 1966 to 1986. Opis' 4 includes protocols from Central Committee plenums held between 1966 and 1990. Opis' 5 comprises documents from plenums held

2. In the Soviet/Russian archival lexicon, the word opis' refers both to a segment of a fond and to the finding aid or catalog that specifies what is contained in that segment.

3. 'Perechen' dokumentov Arkhiva Prezidenta Rossiiskoi Federatsii, Tsentra khraneniia sovremennoi dokumentatsii, Rossiiskogo tsentra khraneniia i izucheniia dokumentov noveishei istorii, Tsentra khraneniia dokumentov molodezhnykh organizatsii, rassekrechennykh Komissiei po rassekrechivaniiu dokumentov, sozdannykh KPSS, v 1994-1995,” Moscow, 1996. A slightly abridged version of this list was published in Novaia i noveishaia istoriia, 3 (May-June 1996): 249-253.

4. Conversation in Moscow between the author and Natal'ia Tomilina, director of TsKhSD, 14 July 1997. This was not the only aspect of the commission's report that was highly misleading. The report contains fond and opis' numbers of collections that supposedly have been "declassified," but it fails to mention that a large number of dela in many of these opisi are in fact still classified. For example, the commission's list of "declassified documents" includes opis' 128 of fond 17 at RTsKhIDNI, which is divided into two volumes. One would expect, based on this listing, that all documents from both volumes of the opis' would be freely accessible, but it turns out that the entire second volume, amounting to 504 dela, is still classified, and even in the first volume only some of the 702 dela are actually available to researchers. (The only way to determine which files in the first volume are really declassified is to ask the head of the RTsKhIDNI reading room before submitting a request.) Similarly, at TsKhSD only a small fraction of the dela in many of the purportedly"declassified" collections are genuinely accessible. Even when files at TsKhSD are nominally "declassified," they may still be off limits because they supposedly contain "personal secrets" (lichnye tainy), which have to be processed by an entirely separate commission. Because of the barriers posed by classified files and files that allegedly contain personal secrets, very few files from some of the "declassified" opisi at TsKhSD are actually given out. (This problem is compounded when, as in the case of opisi 22 and 28 of fond 5 at TsKhSD, only the film reels are lent out. If one delo on a reel is proscribed, all other dela on the reel are also off limits unless a researcher can convince the archivists to have a staff member serve as a monitor for several hours while the researcher uses the "permitted" dela on the reel.) 
between 1986 and 1990, the core of the period when Mikhail Gorbachev was CPSU General Secretary.

Opis' 1 of fond 2 consists of 822 separate dela, with materials arranged in the order in which they were produced. The files include transcripts and other documents from Central Committee plenums held between 1941 and 1966. In principle, the plenum materials from before 1953 should be housed at RTsKhIDNI rather than at TsKhSD. However, to maintain the integrity of the fond, the earlier materials will be kept together with the more recent documents. All told, opis, 1 covers 51 plenums:

5 May 1941 (delo 1a)

10 October 1941 (d. 2)

27 January 1944 (d. 3-5)

11, 14, and 18 March 1946 (d. 6-8)

21, 22, 24, and 26 February 1947 (d. 9-20)

16 October 1952 (d. 21-22)

5 March 1953 (d. 23-24)

14 March 1953 (d. 25-26)

2-7 July 1953 (d. 27-45)

3-7 September 1953 (d. 46-61)

23 February-2 March 1954 (d. 62-89)

21-24 June 1954 (d. 90-109)

25-31 January 1955 (d. 110-138)

4-12 July 1955 (d. 139-180)

13 February 1956 (d. 181-184)

27 February 1956 (d. 185-187)

22 June 1956 (delo 188)

20-24 December 1956 (d. 189-208)

13-14 February 1957 (d. 209-221)

22-29 June 1957 (d. 222-259)

28-29 October 1957 (d. 260-272)

16-17 December 1957 (d. 273-284)

25-26 February 1958 (d. 285-298)

26 March 1958 (d. 299-303)

6-7 May 1958 (d. 304-318)

17-18 June 1958 (d. 319-327)
5 September 1958 (d. 328-332)

12 November 1958 (d. 333-338)

15-19 December 1958 (d. 339-360)

24-29 June 1959 (d. 361-397)

22-26 December 1959 (d. 398-448)

4 May 1960 (d. 449-452)

13-16 July 1960 (d. 453-485)

10-18 January 1961 (d. 486-536)

19 June 1961 (d. 537-543)

14 October 1961 (d. 544-548)

31 October 1961 (d. 549-553)

5-9 March 1962 (d. 554-582)

23 April 1962 (d. 583-587)

19-23 November 1962 (d. 588-623)

18-21 June 1963 (d. 624-658)

9-13 December 1963 (d. 659-696)

10-15 February 1964 (d. 697-743)

11 July 1964 (d. 744-747)

10 October 1964 (d. 748-753)

16 November 1964 (d. 754-764)

24-26 March 1965 (d. 765-786)

27-29 September 1965 (d. 787-805)

6 December 1965 (d. 806-812)

19 February 1966 (d. 813-817)

26 March 1966 (d. 818-822)

In many cases, two or more versions of the same plenum exist. The closest thing to a verbatim transcript, known as an "uncorrected stenogram" (nepravlennaia stenogramma), was compiled by a team of stenographers during the plenum. Excerpts from this raw text were sent by the head of the CPSU CC General Department to all those who spoke at the plenum. The speakers were permitted to see and edit only their own remarks. ${ }^{5}$ The full text then underwent further editing by one or two senior party officials. The corrected version, known as the "author's copy" (avtorskii ekzempliar), contains the full verbatim text marked up in

5. See, for example, the standardized form (classified "sekretno") that was circulated along with appropriate transcript pages to each speaker, TsKhSD, f. 2, op. 1, d. 268, 1. 15. 
handwriting as well as newly drafted pages and paragraphs to be inserted into the transcript. (Often the insertions were in handwriting, too.) The revised version was then retyped to produce a "corrected copy" (korrektorskii ekzempliar), which was given to a few senior Presidium/Politbiuro members to review. ${ }^{6}$ Usually, one of the officials (e.g., Mikhail Suslov) would approve the corrected copy as the final version, but in a few cases each official would make additional changes, resulting in an "edited copy" (redaktsionnyi ekzempliar). A few last-minute revisions might then be made in the edited copy before a final "stenographic account" (stenograficheskii otchet) was typeset. The whole process of editing and revision could sometimes take several months or longer. ${ }^{7}$ The final stenographic account was disseminated to all members of the CPSU Presidium/Politbiuro, CPSU Secretariat, and CPSU Central Committee, to other senior employees of the central party apparatus, to leading officials in the fourteen union-republic Communist parties, and to the first secretaries of the CPSU's territorial, regional, provincial, municipal, and local committees.

The different versions of the proceedings were preserved for most, but not all, of the 51 plenums in opis' 1 of fond 2 . The status of each version is specified clearly both in the opis' and on the cover of each delo. The dela for a particular version are grouped consecutively, which makes it relatively easy to distinguish them from other versions.

In addition to the transcripts of plenum proceedings, opis' 1 includes many files of documents that were used or distributed at the plenums. These documents in some cases were publicly available after the plenums, but in other cases they were classified "secret" or "top secret" and issued on a highly restricted basis. For certain plenums, a separate delo contains the resolutions and theses (or drafts) approved by the Central Committee as well as any final comments by senior party officials.

Although opis' 1 , like all the other opisi of fond 2, is officially described as "declassified," selected materials in opis' 1 (and in the other four opisi of fond 2) are in fact still classified and are marked as such (ne rassekrecheno) in the opis'. The fact that some materials in fond 2 have not yet been declassified is one of the reasons that TsKhSD has been allowing researchers to use the original, bound transcripts and documents, rather than microfilms of them. The listing of sequential numbers for microfilm reels in the opisi leaves no doubt that all the dela in fond 2 have been filmed, but the reels mix classified with declassified materials. Hence, only the hard copies are being loaned out. ${ }^{8}$ Although the continued classification of some materials in fond 2 is vexing and unwarranted, the opportunity for scholars to

6. The name of the CPSU CC Politbiuro was changed to the "CPSU CC Presidium" at the XIX Party Congress in October 1952. The name was changed back to the Politbiuro just before the XXIII Party Congress in March 1966.

7. See, for example, "Tov. Sukovoi E. N.," 18 March 1958, memorandum on materials to include in the final stenographic account of the plenum held on 28-29 October 1957, TsKhSD, f. 2, op. 1, d. 269, 1. 79, as well as the attachment on 11. 80-145.

8. This is in contrast to the plenum documents in opis' 2 of fond 17 at RTsKhIDNI. RTsKhIDNI gives out only the microfilms of these documents. 
use the original documents (rather than the more cumbersome and, in certain cases, barely legible microfilms) is a welcome, if perverse, benefit of this obsessive secretiveness.

\section{The context of the plenum materials}

Through almost the whole of the Soviet era, very little information about CPSU Central Committee plenums was released to the public. During the long reign of Iosif Stalin (1929-1953), virtually nothing about Central Committee plenums was disclosed. That pattern continued for several years after Stalin's death. Transcripts of key plenums during Nikita Khrushchev's consolidation of power (e.g., the sessions in July 1953, January 1955, July 1955, February 1956, June 1957, and October 1957) were not publicly disseminated at all. This policy of strict secrecy was eased during the final years of Khrushchev's tenure, when edited "stenographic accounts" of some plenums were published. Although the appearance of these transcripts was a major step forward, the accounts did not always enable readers to determine precisely what went on at the plenums. Moreover, the publication of stenographic accounts ceased in March 1965, five months after Leonid Brezhnev displaced Khrushchev; and from that point until the end of the 1980s information about Central Committee plenums was as exiguous as it had been in Stalin's time. The lone exception came in June 1983 during Iurii Andropov's brief tenure as CPSU General Secretary, when the stenographic account of a plenum was released and published. ${ }^{9}$ Aside from that, the only materials released during the two decades under Brezhnev and his immediate successors, Andropov and Konstantin Chernenko (and even during the first few years of the Gorbachev era), were brief announcements (informatsionnye soobshcheniia) that Central Committee plenums had been held, lists of those who had spoken, and the resolutions (postanovleniia) and theses (tezisy) adopted by the plenums, which revealed nothing about the tenor of the meetings and the documents used there. ${ }^{10}$ The opening of fond 2 thus fills an important gap in the historical record.

Nevertheless, scholars who use the newly declassified plenum materials should bear in mind a number of caveats. First, it is important to recognize that the Central

9. Plenum Tsentral'nogo Komiteta KPSS, 14-15 iiunia 1983 goda. Stenograficheskii otchet (Moscow: Politizdat, 1983).

10. Useful compilations of the materials published after Central Committee plenums from 1953 through the late 1980s are available in two sources: Kommunisticheskaia partiia Sovetskogo Soiuza v rezoliutsiiakh i resheniiakh s"ezdov, konferentsii, i plenumov TsK, various editions (Moscow: Politizdat, various years); and the 29 volumes of the CPSU yearbook published between 1957 and 1989, Spravochnik partiinogo rabotnika (Moscow: Politizdat, published biennially until the mid-1960s and annually thereafter). From 1989 to 1991, the new Central Committee journal Izvestiia TsK KPSS featured stenographic accounts of selected plenums, including some from the pre-Gorbachev era. 
Committee was not a decision-making body. ${ }^{11}$ The list of plenums in opis' 1 , provided above, underscores just how limited the Central Committee's role was in Soviet policy-making, especially during the Stalin era, when the Central Committee almost never met. During the final twelve years of Stalin's life, the Central Committee convened only six times, for a total of ten days. The extremely infrequent and perfunctory nature of Central Committee plenums was part of Stalin's general policy of weakening subordinate structures that might in some way infringe on his immense personal power. Under Khrushchev, the frequency of plenums increased, but the Central Committee still convened no more than a total of fifteen days in a given year, and usually far less. Moreover, the timing of plenums did not settle into a particular pattern. All members of the Central Committee had full-time jobs elsewhere, which consumed the vast bulk of their energies and attention.

Even on the rare occasions when the Central Committee met, it usually functioned as little more than a rubber stamp for the Presidium/Politbiuro's decisions. As interesting and valuable as the plenum documents are, they clearly show that, with the exception of the June 1957 plenum, all key decisions had been arranged in advance by the Presidium/Politbiuro, which met shortly before the plenums to iron out any differences and approve the plenum agenda and resolutions. It is telling that in some instances the drafts of resolutions, prepared several days before the Central Committee convened, would already say that the resolutions had been "adopted unanimously" — a result that clearly was not in doubt. ${ }^{12}$

The June 1957 plenum was a special case because Khrushchev had been outvoted on the Presidium by what became known as the "Anti-Party Group." During a session of the Presidium from 18 to 21 June 1957, only three of the ten other full Presidium members - Anastas Mikoian, Mikhail Suslov, and Aleksei Kirichenko - had supported Khrushchev. Through last-ditch maneuvers, Khrushchev was able to stave off his dismissal by forcing the convocation on 22 June of a Central Committee plenum, which he knew would take his side in the dispute. That session marked the only time from the mid-1920s onward when the top leaders had failed to reach a consensus beforehand about the results they hoped to achieve at the plenum.

The fact that the general outcomes of the plenums were arranged in advance does not mean that the discussions were dull and lacking in substance. On the

11. The term "Central Committee" refers here exclusively to the body comprising 200300 people who convened for plenums. Even when plenums were not in session, many resolutions and directives were issued in the name of the Central Committee, but these were actually drafted and approved by the Politbiuro or Secretariat, not by the Central Committee itself. Soviet officials also frequently used the term "Central Committee" to refer to the whole central party apparatus, but this, too, gives a misleading impression of the Central Committee's role. The term is used here only in its narrowest sense.

12. See, for example, the marked-up draft "Postanovlenie Plenuma TsK KPSS. Ob uluchshenii partiino-politicheskoi raboty v Sovetskoi Armii i Flote," October 1957 (Secret), in "Materialy k Protokolu No. 5 zasedaniia Plenuma TsK KPSS 28-29. 10. 1957 g.," TsKhSD, f. 2, op. 1, d. $261,11.69-74$. 
contrary, in many cases the debates were very lively and the top leaders provided important information to the rank-and-file Central Committee members about salient issues and controversies. Even so, it is clear from the transcripts and other materials that the Presidium/Politbiuro carefully stage-managed and orchestrated the plenums to produce a desired result. The plenums were extremely useful for the top leaders in many ways - by giving ordinary Central Committee members a sense of involvement in the policy-making process, by ensuring wide support within the party for the top leaders' policies and objectives, and by conferring a formal stamp of legitimacy on the Presidium/Politbiuro's actions — but this does not change the basic fact that key decisions were actually made by the Presidium/ Politbiuro, not by the Central Committee.

The highly circumscribed nature of the Central Committee's role was broadly understood even before any of the plenum materials were declassified. It is not at all surprising that the plenum transcripts would confirm that the Central Committee routinely complied with the Presidium/Politbiuro's wishes. The notion of a "circular flow of power" - whereby the top party leader and his allies chose (and had the power to dismiss) lower-ranking personnel, who in turn were empowered to vote for delegates to the party congress, who in turn elected the members of the Central Committee, who in turn were responsible for electing the highest party organs - had long enabled Western scholars to understand why the Central Committee, despite nominally being empowered to countermand the Presidium/ Politbiuro, instead was staunchly supportive of the top leaders' preferences. ${ }^{13}$ The members of the Central Committee had an in-built incentive to be loyal, resting on self-interest.

The thing that researchers need to bear in mind, then, is that the sudden availability of the plenum materials should not lead to an exaggeration of the Central Committee's role. The documents must be seen in context. Some of the plenum transcripts and supplementary materials contain valuable information that is not readily available from other declassified documents, and this will be of great benefit. But unless the plenums are evaluated against the wider backdrop of Soviet politics (in which the Presidium/Politbiuro was the dominant organ), there is a danger that some scholars will end up "looking for their keys where the streetlight is." 14

This temptation may be particularly strong because the vast majority of records of Presidium/Politbiuro meetings from the post-Stalin era have not yet been released. Detailed notes from Presidium meetings during the Khrushchev era,

13. The term "circular flow of power" was coined by Robert V. Daniels in "Soviet politics since Khrushchev," in John W. Strong, ed., The Soviet Union under Brezhnev and Kosygin (New York: Van Nostrand — Reinhold, 1971): 20. Daniels had developed the basic interpretation at some length more than a decade earlier in his The conscience of the Revolution (Cambridge, MA: Harvard University Press, 1960), and similar views had been elaborated by numerous scholars such as Merle Fainsod and Leonard Schapiro.

14. On this general problem, see Mark Kramer, "Archival research in Moscow: Progress and pitfalls," Cold War International History Bulletin, 3 (Fall 1993): 34. 
compiled by the head of the CPSU CC General Department, Vladimir Malin, exist in fond 3 at TsKhSD, but only a tiny fraction of these had been released as of mid-1999, despite earlier promises that the full collection would be declassified by the end of $1996 .{ }^{15}$ Verbatim transcripts were kept for Politbiuro meetings during the Brezhnev era and afterwards, but only a minuscule portion of these have been released so far. In late 1991 and 1992, some Politbiuro transcripts (or portions of transcripts) were declassified for a short-lived trial of the Soviet Communist Party at the Russian Constitutional Court. ${ }^{16}$ The bulk of the selected transcripts were from the Gorbachev era (mainly because Russian president Boris El'tsin hoped they would embarrass Gorbachev), but even these materials represented only a small fraction of the sessions held between 1985 and 1991. Although a few additional Politbiuro transcripts from the Gorbachev era have been published since the early 1990s - some were put out by the Gorbachev Foundation to offset the impact of the materials released by the El'tsin administration, and others were featured in the Russian archival service's journal Istochnik - these scattered documents are no substitute for access to the full collection. ${ }^{17}$ Moreover, only a handful of transcripts have been released for Politbiuro meetings from the Brezhnev, Andropov, and Chernenko periods (though a few well-placed Russian officials have been given access to the full collection of transcripts). The unavailability of most of the Politbiuro notes and transcripts may create at least some temptation to ascribe too large a role to the Central Committee and other agencies whose records are now available.

The dominance of the CPSU Presidium/Politbiuro in the Soviet policy-making process was necessarily reflected in the Central Committee plenums. The context of each plenum can be understood only by answering several questions: What was the Presidium/Politbiuro hoping to derive from the plenum? Why did the Presidium/Politbiuro decide to convene the Central Committee? What steps were taken to ensure that the plenum bolstered the Presidium/Politbiuro's aims? So long as the Politbiuro's records remain largely sealed, definitive answers to these questions may not always be possible; but the transcripts of the plenums and other

15. For an analysis and translation of these notes and supplementary materials, see Mark Kramer, "Special feature: New evidence on Soviet decision-making and the 1956 Polish and Hungarian crises," Cold War International History Bulletin, 8-9 (Winter 1996-1997): 358-410.

16. Almost all of the transcripts that were released in the early 1990s are now accessible in fond 89 of TsKhSD. For a convenient, cross-indexed, and chronological list of these transcripts compiled by I. I. Kudriavtsev and edited by V. P. Kozlov, see Arkhivy Kremlia i Staroi ploshchadi. Dokumenty po "delu KPSS." Annotirovannyi spravochnik dokumentov, predstavlennykh $V$ Konstitutsionnyi sud RF po “delu KPSS" (Novosibirsk: Sibirskii khronograf, 1995).

17. The two most valuable collections put out by the Gorbachev Foundation are Mikhail Gorbachev, ed., Gody trudnykh reshenii (Moscow: Alfa-Print, 1993); and A. V. Veber et al., eds., Soiuz mozhno bylo sokhranit'. Belaia kniga. Dokumenty i fakty o politike M. S. Gorbacheva po reformirovaniiu i sokhraneniiu mnogonatsional'nogo gosudarstva (Moscow: Aprel'-85, 1995). Some relevant items also have appeared in the Foundation's journal Svobodnaia mysl'. The items published in Istochnik (e.g., about the Politbiuro's immediate reaction to the Chernobyl accident) seem to have been released for the same reason that materials were turned over earlier to the Constitutional Court. 
documents often permit well-founded conclusions. For example, it is now clear that the plenum in early July 1953 which denounced the "criminal anti-party and antistate activities of [Lavrentii] Beria" was convened by Beria's rivals to reassure the Central Committee that Beria's arrest had been a matter of high principle, and not simply part of a power struggle. The Presidium members who had ordered Beria's arrest outdid one another at the plenum in recounting the alleged iniquities of their deposed colleague, accusing him of actions that they themselves had initiated (or at least strongly backed) during the previous few months. Khrushchev, Viacheslav Molotov, Georgii Malenkov, Nikolai Bulganin, and their allies orchestrated the plenum to cover up their own roles in promoting policies for which they were now holding Beria solely accountable. So egregious was their abrupt disavowal of their own actions and views that the plenum often took on a surreal quality. ${ }^{18}$ The rankand-file members of the Central Committee, having long been accustomed to accept whatever they were told by the highest party authorities, went along obediently this time as well.

The stenographic account of the July 1953 plenum was declassified and published in early 1991, and it has been cited by many Western and Russian scholars since then. ${ }^{19}$ Unfortunately, most of these scholars have failed to take due account of the context of the plenum. Rather than seeing the plenum for what it was - namely, an attempt by Beria's rivals to rationalize their actions by blaming the ousted security chief for a host of purported "crimes" - many researchers have taken at face value the allegations made against Beria. This has been especially true of the claims about Beria's supposed effort to "destroy the people's democratic regime in [East Germany]." Beria's real views about Germany in the spring of 1953 bore little resemblance to the accusations lodged against him. It was Molotov, not Beria, who had taken the lead in forging the new Soviet policy toward Germany after Stalin's death, and all the other top Soviet officials, including Beria, had supported him. ${ }^{20}$ The views attributed to Beria were contrived by Molotov to gloss over his own responsibility for having drastically reshaped Soviet Deutschlandpolitik just before the June 1953 uprising in East Germany. Numerous Western and Russian scholars who have used the

18. In a typical case, Khrushchev attributed to Beria "dangerous and counterrevolutionary" policies that Khrushchev himself had devised only a few weeks earlier for Latvia, Estonia, and Moldavia. See "Voprosy Latviiskoi SSR (Proekt)," 7 June 1953 (Top Secret), "Voprosy Estonskoi SSR (Proekt)," 8 June 1953 (Top Secret), and "Voprosy Moldavskoi SSR (Proekt)," 8 June 1953, all from N. S. Khrushchev to the CPSU Presidium, TsKhSD, f. 5, op. 30, d. 6, 11. 20-29; f. 5, op. 15, d. 445, 11. 46, 267-277; and f. 5, op. 15, d. 443, 11. 29-59, respectively.

19. For the published version, see "Delo Beriia," two parts, in Izvestiia TsK KPSS, 1 (January 1991): 139-214, and 2 (February 1991): 141-208. As discussed below, the published stenographic account differs substantially from the verbatim transcript, though the comments here apply just as much to the verbatim transcript.

20. For extensive evidence of this, see my two-part article on "The early post-Stalin succession struggle and upheavals in East-Central Europe: Internal-external linkages in Soviet policymaking," Journal of Cold War Studies, 1, 1 (Winter 1999): 3-55 and 1, 2 (Spring-Summer 1999), forthcoming. 
published stenographic account of the July 1953 plenum have been far too accepting of Molotov's tendentious portrayal of Beria and Germany. ${ }^{21}$

The misunderstandings that have arisen from the declassified account of the July 1953 Central Committee plenum underscore the need for circumspection when drawing on the materials in fond 2. Unless scholars constantly bear in mind the purpose and context of each plenum, they risk going astray in their interpretations of substantive issues as well as of the dynamics of Soviet policy-making.

One additional problem that researchers may encounter when using the new plenum materials is the distortions that sometimes crept in during the editing of the Central Committee transcripts. As noted above, fond 2 contains two or more versions of most of the plenums. For research purposes, the most useful version is the "author's copy," which contains a verbatim transcript with handwritten changes and handwritten or typed insertions. This version of the transcript enables scholars to see both the original proceedings and the changes that senior officials wanted to make. If scholars consult only the "corrected copy" or the "stenographic account," they are likely to miss some important nuances in the original proceedings. For example, by the time a stenographic account was issued for the July 1953 plenum, numerous modifications had been made to cast as sinister a light as possible on Beria's actions. A comparison with the verbatim transcript shows that, among other things, Beria's views about Germany were depicted in far more extreme terms in the edited account. At one point in the verbatim transcript, Molotov claimed that Beria had supported a united Germany "which will be peaceloving and under the control of the four powers." 22 (Molotov conveniently neglected to mention that this was precisely the position he himself had long supported.) To be on the safe side, the words "and under the control of the four powers" were omitted from the stenographic account, thus implying that Beria had wanted the Soviet Union simply to abandon East Germany. Numerous other changes of this sort were made, including some of much greater length. All of them were designed to bring even greater discredit upon Beria.

For most of the other plenums as well, extensive changes were made in the transcripts before stenographic accounts were issued. In some cases lengthy portions were rewritten, and several new paragraphs or even new pages were added. On occasion, entirely new speeches were inserted. ${ }^{23}$ The finished product is valuable, indeed essential, for scholars to consult, but it can be highly misleading unless it is compared with the verbatim transcript. Only the "author's copy" permits researchers to examine simultaneously the original proceedings and the subsequent

21. Even a prominent scholar like Amy Knight, who is deservedly skeptical of many of the charges lodged against Beria, uncritically accepts the statements made about East Germany. See her Beria: Stalin's first lieutenant (Princeton, NJ: Princeton University Press, 1993): 193-200.

22. "Plenum Tsentral'nogo Komiteta KPSS, 2-7 iiulia 1953 g.," July 1953 (Strictly Secret), TsKhSD, f. 2, op. 1, d. 29, 1. 51 .

23. This was the case, for example, with the plenum on 24-26 March 1965. A new, 22-page text was inserted by Mikhail Suslov in place of his original report to the plenum, "Soobshchenie ob itogakh Konsul'tativnoi vstrechi kommunisticheskikh i rabochikh partii," TsKhSD, f. 2, op. 1, d. 766, 11. 81-102. Suslov indicated at the bottom of the new version that " $[\mathrm{t}]$ his text should be used in place of the stenogram." 
editing. ${ }^{24}$ If that version is not available, it is important to look at both the "uncorrected stenogram" and the "stenographic account." In a few cases (e.g., the December 1959 plenum) these two versions do not differ markedly, but in the large majority of cases the differences can be of great importance.

\section{Selected plenum highlights}

Most of the Central Committee plenums between 1941 and 1966 had no direct bearing on foreign policy. Instead they focused on agricultural policy, economic problems, local party management, and the like. A number of the plenums, however, dealt at length with foreign policy issues. Some plenums covered two or more topics, both external and internal, whereas other plenums focused exclusively on important foreign developments. Plenums that approved changes (or impending changes) in the leadership, as in March 1953, July 1953, January 1955, June 1957, October 1957, and October 1964, also are of great importance for studies of the Cold War. In a brief article of this sort it would be impossible to give an exhaustive overview of the many issues covered by the plenums, but a few highlights will suffice to indicate how rich some of the material is.

\section{Intensity of the post-Stalin leadership struggle}

One of the most intriguing aspects of the plenums from 1953 through 1957 is what they reveal about the leadership struggle. Western observers had long surmised that a fierce struggle was under way behind the scenes, but the only direct evidence for this at the time was the occasional announcement that a senior official had been dismissed or demoted. The declassified transcripts of Central Committee plenums, as well as other new documents and first-hand accounts, reveal that the leadership struggle was even more intense than most analysts had suspected. At some plenums, notably those in July 1953, when the Central Committee denounced Beria, in January 1955, when Malenkov came under sharp criticism prior to his dismissal as prime minister, in February 1956, when preparations were under way for Khrushchev's "secret speech" condemning Stalin, in June 1957, when Khrushchev ousted the Anti-Party Group, and in October 1957, when Khrushchev

24. Sometimes, the changes that turn up can be both amusing and revealing about events and individual leaders. For example, at the plenum in late October 1957, a few weeks after the Soviet "Sputnik" had been launched into orbit, Khrushchev boasted that "We now have European missiles, which can strike targets all over Europe without leaving our territory." In the left-hand margin of the verbatim transcript, the first editor wrote a large question mark next to this passage. The second editor changed it to read: "We now have medium-range missiles, that is, European missiles, which can strike targets all over Europe after being launched from our territory." See the marked-up verbatim transcript "Rech' tov. N. S. Khrushcheva na Plenume TsK KPSS, 29 oktiabria 1957 goda," 29 October 1957 (Strictly Secret), in "Plenum TsK KPSS, oktiabr' 1957 goda: Stenogramma chetvertogo zasedaniia Plenuma TsK KPSS," TsKhSD, f. 2, op. 1, d. 269, 1. 66 (hereafter: "Rech' tov. N. S. Khrushcheva"). 
removed his erstwhile ally and defense minister, Marshal Georgii Zhukov, the leadership struggle dominated the sessions. Yet even at plenums that were ostensibly convened for other reasons, the ferocity of the leadership struggle often affected the entire proceedings.

One of the best examples came at the lengthy plenum in July 1955, which focused on several topics, including the recent rapprochement with Yugoslavia. During the debate about Yugoslavia, one of Khrushchev's chief rivals, Viacheslav Molotov, came under fierce attack. At this juncture, barely a year-and-a-half after Beria had been executed, the prospect of losing out in the power struggle still implied potentially grave risks. Even so, Molotov largely held his ground and only grudgingly, at the very end of the plenum, sought to propitiate his attackers. The segment of the plenum that dealt with Yugoslavia featured a lengthy (138-page) opening speech by Khrushchev, which provided a detailed, highly informative (albeit selective and tendentious) overview of the reasons for the Soviet-Yugoslav split under Stalin. 25 (Much of the blame was laid on "the provocative role of Beria and Abakumov.") Toward the end of the speech, Khrushchev revealed to the Central Committee that the Presidium had "unanimously" decided to report that Molotov had "consistently adopted an incorrect position" on the Yugoslav question and had "refused to disavow his incorrect views." 26 Khrushchev read aloud the Presidium's conclusion that "Cde. Molotov's position on the Yugoslav matter does not serve the interests of the Soviet state and the socialist camp and does not conform with the principles of Leninist policy."

Khrushchev's comments touched off a spate of denunciations of Molotov's views on Yugoslavia. One such attack came from Georgii Malenkov, who, despite having lost his post as prime minister four months earlier, was still a key figure on the CPSU Presidium:

"If we speak about Cde. Molotov's main mistake, I would say it is that, contrary to new facts and contrary to everything that has happened over the past two years - and contrary to the overwhelmingly positive results that the CC Presidium has achieved from the steps it has taken to develop friendly relations with Yugoslavia - contrary to all this, he persists in embracing the position laid out by him and by Comrade Stalin in 1948-1949 in their letters to the Yugoslav leadership." 27

Malenkov emphasized that "Cde Molotov still does not acknowledge that his errors in the tactics of struggle played a huge and decisive role in bringing about the split with Yugoslavia." Malenkov noted that Molotov had "blatantly disregarded the

25. Khrushchev's speech, "Doklad Pervogo sekretaria TsK KPSS Khrushcheva N. S. 'Ob itogakh sovetsko-iugoslavskikh peregovorov'," is in "Plenum TsK KPSS, XIX Sozyv: Stenogramma desiatogo zasedaniia 9 iiulia 1955 g. (utrennego),” July 1955 (Strictly Secret), TsKhSD, f. 2, op. 1, d. 172, 11. 1-138.

26. Ibid., 1. 105.

27. "Plenum TsK KPSS, XIX Sozyv: Stenogramma trinadtsatogo zasedaniia 11 iiulia $1955 \mathrm{~g}$. (vechernego)," July 1955 (Strictly Secret), TsKhSD, f. 2, op. 1, d. 175, 11. 135-136. 
instructions of the CC Presidium" during the preparations for the rapprochement with Yugoslavia, adding that "this is typical of him." Molotov's views, according to Malenkov, were "weakening the forces of the camp of socialism and strengthening the forces of the imperialist camp." Malenkov "demanded from [Molotov] a full-fledged explanation and a statement about his obligation to rectify his behavior and to disavow his erroneous views in an unequivocal manner."28

Some of the other condemnations of Molotov during the sessions on Yugoslavia extended far beyond the Yugoslav question alone. Maksim Saburov argued that Molotov's "ridiculous" position on Yugoslavia was "one in a long series of issues on which Cde. Molotov does not agree with the CC Presidium." Saburov cited the virgin lands scheme (which, he said, Molotov believed would be a "largely ineffective and dubious pursuit"), the new planning system for agriculture, the negotiations on the Austrian State Treaty, and the appointment of a new prime minister as issues "on which Cde. Molotov disagreed with the principled and correct stance adopted by the CC Presidium." 29 Saburov claimed that Molotov's "deviations" on these matters were far from innocent, being "directed against Cde. Khrushchev. [...] I personally believe that Cde. Molotov regards Cde. Khrushchev as an unsuitable official." Saburov then likened Molotov to Beria and implied that Khrushchev should deal with Molotov in the same way they had treated Beria:

"I don't want to say that Cde. Molotov is simply repeating what Beria said; I'm not equating him with Beria, but this is indeed like what we heard from Beria. Cde. Molotov, by the logic of his struggle, objected to any question considered by the CC that had been proposed - coincidentally or not so coincidentally by Cde. Khrushchev. I believe that one might draw the conclusion that Cde. Molotov would not be objecting to these proposals if Cde. Khrushchev did not enjoy the level of trust and support that everyone has in him." 30

Coming so soon after the execution of Beria, Saburov's statements clearly were intended as a threat, which may well have been coordinated with Khrushchev. On some matters, Saburov certainly was acting at Khrushchev's behest, and the whole speech was designed not only to deprecate Molotov, but to bolster Khrushchev's standing. Saburov insisted that he was not trying "to give undue glory to Cde. Khrushchev; he doesn't need that sort of glorification. We know that he commands trust not only in the Presidium, but in our whole party," a line that drew sustained applause.

By the end of the plenum, when sharp exchanges ensued between Khrushchev and Molotov just before Khrushchev's closing speech (which "condemned the line advanced by Cde. Molotov as inimical to our party and a non-Leninist and sectarian position"), it was clear that Molotov had experienced a major setback. But what is

28. Ibid., 1. 149.

29. Ibid., 11. 172-183.

30. Ibid., 1. 179. 
perhaps most striking, in view of the intense criticism Molotov encountered, is that he was able to hold onto his position for another two years and that he very nearly won out over Khrushchev in June 1957. The transcript of the July 1955 plenum thus provides crucial evidence that Khrushchev, despite having consolidated his position a good deal, had by no means overcome his most formidable challenger. Anyone who could withstand and recover from the attacks that Molotov endured during the July 1955 plenum was obviously well-suited to be a constant threat.

\section{Fissures in the Communist world (I): Yugoslavia and Poland}

Quite apart from what the plenum documents reveal about the post-Stalin leadership struggle, they shed intriguing light on the priorities of Soviet foreign policy. One thing that quickly becomes evident from the 822 files in opis' 1 is the importance that CPSU officials attached to ideological relations with other Communist countries. Although no plenums dealt at length with the crises in East Germany in 1953 and Poland and Hungary in 1956 (in contrast to the much more prolonged crisis with Czechoslovakia in 1968-1969, which was the main subject of three separate plenums), numerous plenums during the Khrushchev and early Brezhnev periods focused exclusively, or at least extensively, on the nettlesome problem of relations with Yugoslavia, China, and the world Communist movement. The momentous decision to seek a rapprochement with Yugoslavia in May 1955 was regarded as such an abrupt and, from the ideological standpoint, potentially disorienting change of course that Soviet leaders believed they should explain the move to the full Central Committee. ${ }^{31}$ At a plenum in July 1955, Khrushchev and numerous other Presidium members laid out the basic rationale — that "because of serious mistakes we lost Yugoslavia [my poteriali Iugoslaviiu] and the enemy camp has begun to lure that country over to its side" — and emphasized the "enormous importance of winning back our former loyal ally." Not surprisingly, the Central Committee voted unanimously in support of the Presidium's actions.

Similarly, in later years when tensions reemerged with Yugoslavia (in large part because of the crises in 1956), Khrushchev and his colleagues again believed it wise to explain these tensions to the Central Committee. One such occasion came in December 1957, when a plenum was convened to inform Central Committee members about a two-part conference held in Moscow the previous month to mark the 40th anniversary of the Bolshevik takeover. The leaders of the thirteen ruling Communist parties had been invited to the first part of the conference on 14-16 November, but Yugoslav officials had declined to take part. When the other twelve parties met and issued a statement reaffirming the CPSU's preeminent role in the world Communist movement, Yugoslav leaders refused to

31. The sessions on Yugoslavia in July 1955 were designed to inform the Central Committee about actions already taken, not to consult it in advance. This is fully in line with the analysis above of the Central Committee's role in Soviet policy-making. 
endorse it. ${ }^{32}$ At the CPSU Central Committee plenum a few weeks after the conference, one of the highest-ranking party officials, Mikhail Suslov, who was broadly responsible for ideology and intra-bloc relations, explained to the members that "Yugoslavia's failure to participate [...] attests to the continuing ideological disagreements between the League of Communists of Yugoslavia [LCY] and the other Communist parties of the socialist countries." $33 \mathrm{He}$ cited several areas in which "ideological disagreements remain": the "unwillingness of the Yugoslav comrades to speak about a socialist camp, especially a socialist camp headed by the Soviet Union"; the desire of the Yugoslav authorities to "play their own special and exalted role between West and East"; and the "unduly close relationship" Yugoslavia had established with the United States, a country that was "applying pressure" on the Yugoslavs to "serve as a counterweight to the Soviet Union." Although he insisted that "we have not retreated, and will not retreat, one step from our fundamental positions," he assured the Central Committee that "Yugoslavia's failure to sign the Declaration does not mean that our relations have deteriorated. [...] There is no need to stir up new tensions." "34

When the matter came up again five months later, at a plenum on 7 May 1958, Soviet officials were less accommodating. Although the plenum dealt mostly with other matters, Khrushchev initiated a discussion about Yugoslavia toward the end of the third session. ${ }^{35} \mathrm{He}$ argued that the recent LCY congress had been a "step back toward revisionist, anti-party, and anti-Marxist positions," and he condemned Yugoslavia's close ties with Imre Nagy, the Hungarian leader who had been removed during the Soviet invasion of Hungary in November 1956 and who was put to death in Hungary in June 1958, a few weeks after the CPSU Central Committee plenum. Khrushchev also denounced statements by the Yugoslav leader, Josip Broz Tito, particularly a speech Tito had given in Pula on 11 November 1956, which raised serious concerns about the Soviet intervention in Hungary. Khrushchev informed the Central Committee that the CPSU Presidium had decided not to send a delegation to the LCY congress after the Yugoslavs had changed the agenda at the last minute. He received lengthy applause from the Central Committee when he affirmed that the Soviet Union would continue to offer "principled and constructive criticism" of Yugoslav policy whenever necessary.

It may seem peculiar that Khrushchev would have included these detailed comments about Yugoslavia after a plenum that had dealt with agricultural policy, but his remarks are indicative of the efforts that Soviet leaders made to ensure strong, unwavering support within the CPSU for the latest ideological twists and

32. "Deklaratsiia Soveshchaniia predstavitelei kommunisticheskikh i rabochikh partii sotsialisticheskikh stran, sostaiavshegosia v Moskve 14-16 noiabria 1957 goda," Pravda (November 22, 1957): 1-2.

33. "Plenum TsK KPSS, XX Sozyv: Stenogramma tret'ego i chetvertogo zasedanii plenuma TsK KPSS 16-17 dekabria 1957 g.,” TsKhSD, f. 2, op. 1, d. 282, 1l. 161-182.

34. Ibid., 1.172

35. "Plenum TsK KPSS, XX Sozyv: Stenogramma tret'ego zasedaniia 7 maia 1958 g. (vechernego)," May 1958 (Top Secret), TsKhSD, f. 2, op. 1, d. 317, 11. 57-93. 
turns in relations with Yugoslavia. This is one of many instances in which documents from the former Soviet archives reveal that Yugoslavia was a more important factor for Soviet leaders during the Cold War than most Western observers had realized..$^{36}$

The plenum documents also reveal that Yugoslavia was not the only East European country that complicated Moscow's efforts in the late 1950s to unite the world Communist movement under explicit Soviet leadership. The standoff with Poland in October 1956 had induced Khrushchev to reach a modus vivendi with the

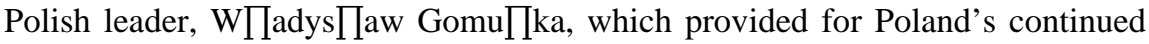
status as a loyal member of the Soviet political and military bloc. ${ }^{37}$ This arrangement was briefly strained in late October and early November 1956 when Gomu \ka insisted on the withdrawal of Marshal Konstantin Rokossowski, the Soviet officer who had been serving as Polish defense minister for the previous

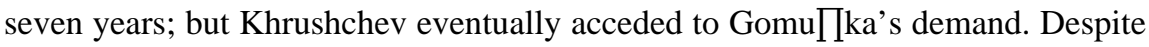
this breakthrough, the plenum materials confirm that Soviet-Polish relations were still marred by occasional frictions. Suslov's report at the December 1957 plenum indicated that the Polish representatives at the world conference of Communist parties in Moscow had been at odds with the Soviet Union on a number of key issues:

"During the preparation of the documents - the Declaration and the Peace Manifesto - the Polish comrades tried to introduce their own slant by ensuring there was no reference to the leading role of the Soviet Union and by avoiding harsh attacks against imperialism, especially against American imperialism. They steadfastly objected to the passage in the Declaration that said American imperialism has become the center of international reaction. The Polish comrades argued that the peculiar circumstances they face in Poland do not yet enable them to embrace the formula 'under the leadership of the Soviet Union.' They claimed that the Declaration is supposedly too bellicose a document and that it could damage relations with the imperialists." 38

Suslov also complained that the Polish delegation's draft of the so-called Peace Manifesto, the document that was due to be approved by the 64 Communist parties attending the second phase of the conference (on 16-19 November), was "seriously deficient" because "it made no mention of where the threat of war originated." He emphasized that the "document prepared by the Polish comrades had to be

36. Among numerous other examples of the important ideological role that Yugoslavia played in Soviet policy-making was the close attention that Soviet leaders paid in 1968 to Yugoslavia's influence on the reformist officials in Czechoslovakia. See, for example, the plethora of documents in TsKhSD, f. 5, op. 60, d. 279, 284. Whenever Soviet leaders detected hints (or what they construed as hints) that "Titoist" ideology was filtering into Czechoslovakia, they raised the issue with the Czechoslovak authorities and discussed the matter at length during CPSU Politbiuro meetings.

37. See M. Kramer, “Special feature...," art. cit.: 360-362.

38. "Plenum TsK KPSS, XX Sozyv: Stenogramma tret'ego i chetvertogo zasedanii plenuma TsK KPSS 16-17 dekabria 1957 g.," TsKhSD, f. 2, op. 1, d. 282, 11. 173-174. 
drastically revised" because "the representatives of the other fraternal parties [including the CPSU] did not support the Polish comrades on even a single point that they raised."

Suslov did not directly impugn the motives of the Polish authorities, but he maintained that "these allusions to some sort of special circumstances in their country don't seem particularly convincing." Khrushchev, for his part, implied that the main reason Polish officials did not want to antagonize the United States is that they were uncertain whether U.S. banks would "still give credits" to Poland if relations deteriorated. ${ }^{39}$ Despite these skeptical comments, both Suslov and Khrushchev acknowledged that "the important thing is that the Polish comrades in the end signed the Declaration, which undoubtedly will have an enormous impact in Poland."

In subsequent years, especially after the emergence of the Sino-Soviet split in the 1960s, GomuПka came more closely into line with the Soviet point of view. Even so, the plenum materials indicate that Khrushchev remained concerned that the defiance Gomu \ka displayed in 1956 and the unorthodox positions he adopted in 1957 might someday resurface.

\section{Fissures in the Communist world (II): China and Albania}

As important as the ideological challenge posed by Yugoslavia may have been, it was nothing compared to the rift that emerged with China at the end of the 1950s. From December 1959 on, an inordinately large number of Central Committee plenums were devoted to the subject of China and the world Communist movement. At a plenum on 22-26 December 1959, Suslov presented a detailed report on "the trip by a Soviet party-state delegation to the People's Republic of China" in October 1959. 40 This report, which had been commissioned by the CPSU Presidium on 15 October (shortly after Khrushchev and the other members of the delegation had returned to Moscow) and was approved in a draft version by the Presidium on 18 December, gave many Central Committee members the first direct inkling they had received of how serious the incipient problems with China were. Although Suslov's report did not feature the strident rhetoric and harsh polemics that would soon characterize Sino-Soviet relations, he spoke at length about the "dangerously foolish ideas of the Chinese comrades," the "egregious economic and intra-party mistakes committed by the Chinese comrades," and the "acute disagreements" between Moscow and Beijing on "basic matters of socialist construction."

39. Ibid., 1. 174.

40. "O poezdke sovetskoi partiino-pravitel'stvennoi delegatsii v Kitaiskuiu Narodnuiu Respubliku," plus extensive modifications and insertions incorporated by Suslov, in "Materialy k Protokolu No. 15 zasedaniia Plenuma TsK KPSS," 22-26 December 1959 (Strictly Secret), TsKhSD, f. 2, op. 1, d. 447, 11. 57-91. For background on this trip, see Mark Kramer, "SinoSoviet relations on the eve of the split," Cold War International History Bulletin, 6-7 (Winter 1995-1996): 170-186. 
In addition to highlighting ideological differences, Suslov enumerated many "foreign policy issues on which major disagreements have surfaced between us and the Chinese comrades," including Mao Zedong's rhetorical dismissal of nuclear weapons as "a paper tiger" (a claim that, in Suslov's view, was "leading the Chinese people to believe that a nuclear war would be an easy matter and that no preparations were needed"); China's aversion to peaceful coexistence with the United States (a policy that, according to Suslov, Chinese leaders "regard as merely a convenient tactical maneuver" rather than a "profound Leninist principle"); China's clumsy handling of negotiations with Japan; the recent exacerbation of tensions between China and India despite Moscow's efforts to mediate (efforts which, Suslov complained, had "not been matched by the requisite understanding on the part of Chinese leaders" because "the Chinese comrades cannot properly evaluate their own mistakes"); and the deterioration of China's relations with Indonesia, Burma, Thailand, and other East Asian countries (a trend that, in Suslov's view, had left China "isolated in the international arena"). Of particular interest were Suslov's comments about Mao's "completely incomprehensible" retreat during the Sino-American crisis that erupted in August 1958 when China began bombarding the offshore islands of Quemoy and Matsu in the Taiwan Straits:

\begin{abstract}
"We [in Moscow] regarded it as our internationalist duty to come out decisively in support of the fraternal Chinese people, with whom our country is bound by alliance obligations. According to secret documents that we had intercepted, it had become clear that the ruling circles in America were already psychologically prepared to relinquish the offshore islands to the PRC. However, after precipitating an extreme situation in the vicinity of the offshore islands and making far-reaching statements, the Chinese comrades backed down at the critical moment. [...] It is obvious that in backing down, the Chinese comrades squandered things. The perception abroad was that they had caved in." 41
\end{abstract}

In all these respects, Suslov argued, "the Chinese comrades are at odds with the common foreign policy line of the socialist camp. The lack of needed coordination between the two most powerful Communist parties on questions of foreign policy is abnormal." 42

After recounting this litany of "serious disagreements," Suslov emphasized that long-standing efforts to increase the appearance and reality of unity within the socialist camp made it imperative to curtail China's deviations in foreign policy:

"The incorrect actions of one of the socialist countries affects the international situation of the entire socialist camp. We must bear in mind that imperialist propaganda directly links the actions of the Chinese comrades with the policy of

41. "O poezdke sovetskoi partiino-pravitel'stvennoi delegatsii v Kitaiskuiu Narodnuiu Respubliku," (see Note 40 supra), 1. 71. The sentence referring to the interception of secret documents and the U.S. government's alleged readiness to surrender Quemoy and Matsu did not appear in Suslov's initial draft. It was added during the revisions shortly before the plenum. 42. Ibid., 1. 80 . 
the USSR and other socialist countries. And indeed, our Communist parties, too, always emphasize that the socialist camp has only one foreign policy course." 43

Suslov declared that the Soviet Union would try to restore "complete unity" by continuing "to express our candid opinions about the most important questions affecting our common interests when our views do not coincide." Although the aim would be to bring China back into line with the USSR, Suslov argued that if these efforts failed, the CPSU Presidium would "stick by the positions that our party believes are correct."

Throughout the report, Suslov insisted that the disagreements were not yet irreparable. He noted several measures that could rapidly improve Sino-Soviet ties, and he pledged that the CPSU Presidium would do all it could to "strengthen and develop Soviet-Chinese friendship and unity" on the basis of "Leninist principles of equality and mutual cooperation." Nevertheless, a key passage in his report may have left some Central Committee members wondering whether relations with China could really be mended, at least while Mao Zedong remained in power:

"It has to be said that all the mistakes and shortcomings in the internal and foreign policies of the Chinese Communist Party can be explained in large part by the cult of personality surrounding Cde. Mao Zedong. Formally, the CC of the Chinese Communist Party abides by the norms of collective leadership, but in reality the most important decisions are made by one man and therefore are often plagued by subjectivism and, in some instances, are simply ill-conceived. By all appearances, the glorification of Mao Zedong in China has been growing inexorably. More and more often, statements appear in the party press that 'we Chinese live in the great era of Mao Zedong.' Comrade Mao Zedong is depicted as a great leader and a genius. They call him the beacon, who is shining the way to Communism and is the embodiment of the ideas of Communism. The name of Mao Zedong is equated with the party, and vice versa. The works of Cde. Mao Zedong are presented in China as the final word of creative Marxism and are placed on a par with the classic works of Marxism-Leninism. [...] All of this, unfortunately, impresses Cde. Mao Zedong, who, judging from everything, is himself convinced of his own infallibility. This is reminiscent of the situation that existed in our country during the final years of I. V. Stalin. We, of course, weren't able to speak with the Chinese comrades about this, but the [CPSU] Plenum must be aware of these aspects of life in the Chinese Communist Party." 44

This part of Suslov's report went well beyond any previous statements that Soviet leaders had made in forums larger than the CPSU Presidium. Up to this point, Soviet officials had said nothing in public about the problems with China, and even in private Moscow's criticism of Mao had been subdued. Despite Suslov's willingness to voice much stronger complaints at the Central Committee plenum, he indicated that a low-key policy should be maintained in public. Although he 
acknowledged that the Soviet Union would not praise or overlook what it believed to be "profound mistakes," he averred that "we shouldn't engage in direct criticism, since this would lead to an unnecessary public discussion which might be construed as interference in the internal affairs of the Chinese Communist Party and would induce our enemies to gloat over the discord between the CPSU and the Chinese Communist Party." Suslov argued that, at least for the time being, the CPSU must "avoid public discussions and rely instead on private meetings and other contacts between the two parties to explain our position to the Chinese comrades."

Despite Suslov's hopes that the situation could be rectified and that public polemics could be avoided, the Sino-Soviet split continued to widen. Tensions increased rapidly in the first few months of 1960, culminating in the publication of a lengthy statement by Chinese leaders in April 1960 during celebrations of the 90th anniversary of Lenin's birthday. ${ }^{45}$ The statement, entitled "Long live Leninism," removed any doubts that Soviet officials and diplomats still had about the magnitude of the rift between the two countries. ${ }^{46}$ Soon thereafter, in early June 1960, all the East European governments became aware of the conflict when Chinese officials voiced strong criticism of the Soviet Union at a meeting in Beijing of the World Federation of Trade Unions (WFTU). The dispute escalated a few weeks later at the Third Congress of the Romanian Communist Party in Bucharest, where Khrushchev sought to rebut the comments expressed at the WFTU meeting and to retaliate for China's decision to provide other delegates with copies of a confidential letter that Khrushchev had sent to the CCP leadership. The top Chinese official in Bucharest, Peng Zhen, responded in kind. ${ }^{47}$

This confrontation was the main topic of discussion at the next CPSU Central Committee plenum, on 14-16 July 1960. Khrushchev designated one of his closest aides on the Presidium, Frol Kozlov, to present a lengthy report to the plenum outlining "the mistaken positions of the CCP CC on fundamental questions of Marxist-Leninist theory and current international relations." 48 Kozlov reiterated all the complaints voiced by Suslov seven months earlier, but the tone of his speech was much more pessimistic. Kozlov accused the Chinese leadership of "acting surreptitiously, behind the backs of the CPSU and the other fraternal parties, to create fissures and rifts in the international Communist movement and to spread its

45. "Long live Leninism!" was first published in Hongqi [Beijing], 8 (16 April 1960), and then republished in translation in Peking Review, 3, 17 (April 1960): 14-22.

46. See, for example, the interview with the former head of the Soviet "missile group" in China, General Aleksandr Savel'ev, in Aleksandr Dolinin, "Kak nashi raketchiki kitaitsev obuchali," Krasnaia zvezda, (May 13, 1995): 6.

47. For a lively account of the Bucharest session, which includes details omitted from the official transcript, see Edward Crankshaw, The new Cold War: Moscow v. Peking (Baltimore: Penguin, 1963): 97-110.

48. "Doklad na Plenume TsK KPSS ob itogakh Soveshchaniia predstavitelei bratskikh partii v Bukhareste i ob oshibochnykh pozitsiiakh rukovodstva TsK KPK po nekotorym printsipial'nym voprosam marksistsko-leninskoi teorii i sovremennykh mezhdunarodnykh otnoshenii," 13 July 1960 (Strictly Secret), TsKhSD, f. 2, op. 1, d. 472, 11. 2-74. 
own special views, [which] contravene sacred Leninist principles." His speech prefigured the harsh rhetoric that would soon pervade Sino-Soviet exchanges.

At the next CPSU Central Committee plenum, on 10-18 January 1961, the growing acrimony in the world Communist movement was again the main topic of discussion. By this point, the Soviet Union had withdrawn all its military technicians and advisers from China, and had begun recalling its thousands of nonmilitary personnel, causing disarray in many of China's largest economic and technical projects and scientific research programs. ${ }^{49}$ At the plenum, Suslov presented a lengthy and - on the surface - surprisingly upbeat assessment of the "world conference" of 81 Communist parties in Moscow in November 1960. He claimed that the meeting had "successfully resolved all these problems [of disunity in the Communist world] and had marked a new, spectacular triumph of MarxismLeninism in the international Communist movement." ${ }_{50}$ The Soviet Union, he declared, could now "tirelessly work to strengthen the unity, cohesion, and friendship" among socialist countries.

Despite this optimistic gloss, much of Suslov's speech at the plenum actually gave grounds for deep pessimism. Although Soviet and Chinese officials had been able to achieve a last-minute compromise that temporarily papered over their differences, this fragile "solution" had been preceded by venomous exchanges. Suslov acknowledged that, from the outset of the conference, "the Chinese Communist leaders not only had declined to reassess their mistaken views, but had grown even more adamant in espousing anti-Leninist and anti-Marxist" policies. Suslov maintained that the CPSU Presidium had "done its best to overcome its disagreements with the leadership of the Chinese Communist Party" through a series of preliminary meetings and contacts, but had failed to persuade the Chinese delegates to alter "their mistaken views on crucial matters." ${ }_{1}$ All the preparatory work for the conference, according to Suslov, had been turned by the Chinese into "a source of discord." The proceedings of the conference itself had not been made public, but Suslov informed the Central Committee that the head of the Chinese delegation, Deng Xiaoping, had delivered two speeches that were sharply at odds with the CPSU's positions, demonstrating "a complete unwillingness to find some way of overcoming the two parties' disagreements." Suslov also noted that the Albanian delegation, led by Enver Hoxha, had sided with the Chinese participants and had expressed "bizarre, malevolent, and dogmatic views aimed solely at causing tension and dividing the conference." 52 Although Soviet leaders had been

49. For a useful account of this process by a participant, see Mikhail A. Klochko, Soviet scientist in Red China (Montreal: International Publishers Representatives, 1964), esp.: 164188. See also A. Dolinin, art. cit.: 6.

50. "Ob itogakh Soveshchaniia predstavitelei kommunisticheskikh i rabochikh partii," in "Materialy k Protokolu No. 18 zasedaniia Plenuma TsK KPSS, 10-18 ianvaria 1961 g.," January 1961 (Strictly Secret), TsKhSD, f. 2, op. 1, d. 495, 11. 11-85. The quoted passage is on 1. 12 .

51. Ibid., 1. 33 .

52. Ibid., 11. 55-57. 
aware since mid-1960 that Albania was aligning itself with China, Hoxha's speech at the November 1960 conference, according to Suslov, had shown for the first time what a "monstrous" form this realignment was taking.

The speeches of the Chinese and Albanian delegations, Suslov told the Central Committee, had been greeted by a torrent of angry criticism. "Everyone at the conference," he claimed, "understood that the Chinese delegation's opposition to certain points," especially to a proposed statement regarding the need to overcome the "pernicious consequences of [Stalin's] personality cult," was motivated by "an awareness that this statement could be directed against all forms of personality cults, including the one in the Chinese Communist Party." 53 Suslov argued that the "mistaken views of the Chinese comrades" would persist so long as Mao Zedong demanded "endless glorification" and "aspired to claim a special role in the development of Marxist-Leninist theory" and the policies of the socialist bloc:

"With the obvious guidance of the CCP leadership, the Chinese press is fanning the personality cult of Cde. Mao Zedong and proclaiming him 'the greatest Marxist-Leninist of our time' (Renmin Ribao, 7 October 1960), in the hope of staking out a special role for Mao Zedong in the international Communist movement. It is hardly accidental that CCP leaders have geared their actions over the past year toward the assumption of a dominant place among the fraternal Communist parties." 54

Suslov acknowledged to the Central Committee that the impasse resulting from the "obduracy" of the Chinese leadership had nearly caused the meeting to collapse. Although Khrushchev was able to reach a compromise with the Chinese delegation in last-ditch talks on 30 November, the bulk of the conference had given little reason to believe that the dispute was genuinely resolved. Suslov tried to put the best face on the whole matter - claiming that "our party achieved a great moralpolitical victory from the conference" and that "one of the most important results of the Moscow Conference was the resumption of close contacts between the CPSU CC and the Chinese Communist Party CC" - but his lengthy account of the conference belied his expressed hope that "there is now a solid basis for the strengthening of Soviet-Chinese friendship and the unity of our parties." 55

The precariousness of the outcome in November 1960 became evident soon after the January 1961 plenum, as the polemics and recriminations resumed behind the scenes with ever greater stridency. Before long, the dispute flared into the open, and news of the Sino-Soviet conflict spread throughout the world. Khrushchev and Mao made a few additional attempts to reconcile their countries' differences, but the rift, if anything, grew even wider. Hopes of restoring a semblance of unity in the international Communist movement were dashed. At CPSU Central Committee plenums from late 1962 on, Soviet leaders no longer held out any hope that the split

53. Ibid., 1.45

54. Ibid., 11. 65-66.

55. Ibid., 11. 78, 87. 
could be surmounted. Instead, they used the plenums to marshal broad support within the party for what was projected to be a long and dangerous struggle against China.

A typical session occurred in December 1963 when Khrushchev, Suslov, and a number of other CPSU Secretaries - Boris Ponomarev, the head of the CPSU CC International Department, Iurii Andropov, the head of the CPSU CC department for intra-bloc relations, and Leonid Il'ichev, the head of the CPSU CC Ideology Department - spoke at length about the "disagreements connected with the willfully divisive actions of the leadership of the Chinese Communist Party." 56 Coming after a year of acrimonious polemics between the Soviet Union and China, the December 1963 plenum featured endless condemnations of "the CCP leadership's resort to open polemics and other actions that, in both form and method, are unacceptable in relations between Marxist-Leninists." The speakers at the plenum claimed that "the CCP leaders are now increasingly trying to carry their profoundly mistaken views on ideological matters into interstate relations [so that] they can destroy the friendship and cohesion of the Communist movement and weaken the anti-imperialist front." To ensure that CPSU members at all levels would be prepared for a confrontation with China, the CPSU Secretariat decided on 16 December 1963 to expand the distribution list for the major speeches given at the plenum. ${ }^{57}$

One of the consistent themes about Sino-Soviet relations at the Central Committee plenums in 1963, 1964, and 1965 was the effort China had been making to lure other Communist states and parties to its camp, building on its success with Albania. As early as the January 1961 plenum, Suslov reported that China had done its best at the November 1960 conference to line up broad support for its "mistaken and divisive" positions:

"I have to acknowledge that there was a small group of waverers. In addition to the Albanians, the Burmese and Malayan representatives usually followed the lead of the Chinese comrades. The reasons for this are clear: namely, that they lived and worked for a long time in Beijing. Besides the Burmese and Malayans, the delegates from the Vietnamese Workers' Party and the Communist parties of Indonesia, Japan, and Australia also showed signs of wavering. These parties are from countries that are geographically close to the PRC, and they have close traditional ties with the CCP. Unusual pressure was applied on their representatives [by the Chinese]." 58

56. See the marked-up versions of the presentations in "Materialy k Protokolu No. 6 zasedaniia Plenuma TsK KPSS, 13 dekabria 1963 g.: O deiatel'nosti Prezidiuma TsK KPSS po ukrepleniiu edinstva kommunisticheskogo dvizheniia, postanovlenie Sekretariata TsK KPSS ob izdanii tekstov vystuplenii na Plenume TsK Ponomareva B. N., Andropova Iu. V., i Il'icheva L. F., rechi sekretarei TsK KPSS Ponomareva, Andropova, Il'icheva, i Khrushcheva N.S.," 9-13 December 1963 (Strictly Secret), TsKhSD, f. 2, op. 1, d. 665.

57. "Vypiska iz protokola No. 90/257gs zasedaniia Sekretariata TsK ot 16.XII.1963 g.," 16 December 1963 (Top Secret), TsKhSD, f. 2, op. 1, d. 693, 1. 4.

58. "Ob itogakh Soveshchaniia predstavitelei kommunisticheskikh i rabochikh partii," (see Note 50 supra), 11. 61-62. 
Over the next few years, Soviet concerns about the fissiparous effects of the SinoSoviet split greatly increased. At the Central Committee plenum in December 1963, Iurii Andropov, the head of the CPSU CC department for intra-bloc relations, claimed that China had been secretly attempting to induce other East European countries to follow Albania's lead. He noted that the Chinese had been focusing their efforts on Poland, Hungary, and East Germany:

"The Chinese leaders are carrying out a policy of crude sabotage in relation to Poland, Hungary, and the GDR. Characteristic of this is the fact that in September of this year, during conversations with a Hungarian official in China, Politbiuro member Chu De declared that China would welcome it if the Hungarian comrades diverged from the CPSU's line. But, Chu De threatened, if you remain on the side of the revisionists, we will have to take a stance against you. ${ }^{59}$

Beijing's contacts with these three countries bore little fruit in the end, but Soviet leaders obviously could not be sure of that at the time. The mere likelihood that China was seeking to foment discord within the Soviet bloc was enough to spark heightened vigilance in Moscow.

Soviet concerns increased still further over the next several months when another Warsaw Pact country, Romania, began seeking a neutral position in the Sino-Soviet dispute. Although the Romanians never went as far as the Albanians in pursuing outright alignment with China, the Romanian leader Nicolae Ceausescu refused to endorse Moscow's polemics or to join in other steps aimed at isolating Beijing. This policy had been foreshadowed as early as February 1964, when Suslov warned the CPSU Central Committee that China was redoubling its efforts to split the Soviet bloc:

\begin{abstract}
"These efforts by the CCP leaders, far from being limited to the ideological sphere, extend into the sphere of practical politics among socialist countries and Communist parties. In seeking to enervate the unity and cohesion of the socialist commonwealth, the CCP leadership resorts to all manner of tricks and maneuvers to disrupt economic and political relations among the socialist countries and to sow discord in their activities on the international arena. Recently, the fissiparous and subversive actions of the Chinese leaders in the world Communist movement have drastically increased. There is no longer any doubt that Beijing is seeking to provoke a schism among the Communist parties and the creation of factions and groups that are hostile to MarxismLeninism." 60
\end{abstract}

59. "Rech' Sekretaria TsK KPSS tov. Andropova Iu. V. na dekabrskom (1963 g.) Plenuma TsK KPSS,” No. P2002, (Top Secret), 9-13 December 1963, TsKhSD, f. 2, op. 1, d. 665, 1. 30.

60. "Bor'ba KPSS za splochennost' mirovogo kommunisticheskogo dvizheniia: Doklad tovarishcha M. A. Suslova na Plenume TsK KPSS 14 fevralia 1964 goda,” P. 480, TsKhSD, f. 2, op. 1, d. 731, 1. 158ob. 
Suslov's warning seemed even more pertinent a year later, when Romania's defiance had become more overt. In April 1964 the Romanian government issued a stinging rejection of Khrushchev's scheme for supranational economic integration within the socialist bloc (a scheme that would have relegated Romania to being little more than a supplier of agricultural goods and raw materials for the more industrialized Communist countries). ${ }^{61}$ From then on, the Romanian authorities began reorienting their foreign trade away from the Soviet Union. By 1965, Romania's divergence from the basic foreign policy line of the Warsaw Pact countries was extending well beyond foreign economic matters. In March 1965, Ceausescu declined to take part in a Consultative Meeting of Communist and Workers' Parties in Moscow, which was designed to lay the groundwork for another world conference of Communist parties, following up on the November 1960 session. Romania's refusal to attend was based, at least in part, on China's boycott of the meeting. Soviet leaders had assured Ceausescu and the Chinese authorities that, in the wake of Khrushchev's ouster in October 1964, there was an opportunity to search for "new approaches and new means of achieving unity in the world Communist movement," but neither the Chinese nor Ceausescu agreed to take up the offer. Romania's absence from the meeting was conspicuous as the only ruling Communist party other than China and Albania that failed to show up. (Officials from Cuba, North Vietnam, Mongolia, and North Korea all attended, as did representatives of several non-ruling Communist parties.)

At a CPSU Central Committee plenum on 24-26 March 1965, Suslov praised the consultative meeting, but noted regretfully that Romania had not taken part. He then accused the Chinese of trying to foment discord within the Warsaw Pact:

"The leadership of the CCP not only is directly supporting factional groups in the fraternal countries, but is also saying that 'in the future this sort of work must be greatly stepped up.' The Chinese leaders declare that their disagreements with the CPSU and the other parties are 'disagreements between two hostile classes, the proletariat and the bourgeoisie,' and hence they reject any attempts to improve relations between our parties." 62

The tone of Suslov's presentation at this plenum was far more somber than his earlier reports. He even warned of Chinese efforts to stir up unrest in the Soviet Union itself, alluding to a student demonstration that Chinese officials had orchestrated in Moscow in early March 1965 to try, as Suslov put it, to "incite an anti-Soviet hysteria." 63 No longer did he hold out any hope that relations with China could be ameliorated. Although Suslov affirmed that "the CPSU Presidium believes it necessary to move ahead patiently, without giving in to provocations,

61. Romanian Press Agency, Statement on the stand of the Romanian Workers' Party concerning problems of the world Communist and working class movement (Bucharest: Agerpres, 1964).

62. "Soobshchenie ob itogakh Konsul'tativnoi vstrechi kommunisticheskikh i rabochikh partii," TsKhSD, f. 2, op. 1, d. 766, 11. 98-99.

63. Ibid., 11. 105-106. 
[...] to show the Chinese people our sincere desire to live with them in friendship," he acknowledged that "the Chinese leadership has completely rejected all the positive suggestions in the communiqué from the Consultative Meeting."

The increasingly harsh tone of the speeches given by Suslov and other Soviet leaders at Central Committee plenums provides a valuable way to track the deterioration of Soviet ties with China. After having sought, at the December 1959 plenum, to caution against public denunciations of China, Suslov over time had to embrace the hostile rhetoric that characterized Sino-Soviet relations. This trend corresponded with the shift in bilateral ties from the amity of the mid-1950s to the tensions in the late 1950s to the bitter dispute of the early and mid-1960s. Once the conflict was fully under way, the pronouncements by Suslov and others at the plenums were intended not only to warn about real dangers from China, but also to reassure the Central Committee that the top leaders would not compromise Soviet interests.

\section{The Zhukov affair}

Normally, the Central Committee was not involved in military policy. That sphere of activity was left to the CPSU Presidium/Politbiuro, the Defense Council, the Ministry of Defense, and the CPSU CC Administrative Organs Department. Military issues were not brought before the Central Committee even for nominal approval. A partial exception came in late October 1957, when Khrushchev decided to oust Soviet defense minister Marshal Georgii Zhukov from all his senior party and ministerial positions. Khrushchev took this step to consolidate his own power, but the affair inevitably had some bearing on civil-military relations. Although it did not represent an institutional clash between civilian and military authorities (and clearly was not motivated by fears that Zhukov would try to seize power in a coup d'état), it reinforced the norm of the army's subordination to civilian (i.e., Communist Party) control. ${ }^{64}$

The declassification of the October 1957 plenum materials, amounting to several thousand pages, does not fully dispel the mystery that has long surrounded the Zhukov affair. Just four months earlier, in June 1957, Zhukov had sided with Khrushchev against the "Anti-Party Group" and had been rewarded for his efforts by being promoted to full membership on the CPSU Presidium. Khrushchev's abrupt shift against Zhukov in October 1957 came as a shock both inside and outside the Soviet Union. The decisive maneuvers to remove Zhukov occurred while the defense minister was on an extended trip to Yugoslavia and Albania in the last few weeks of October, a trip that had been authorized by the CPSU Presidium. When Zhukov began his travels he had no inkling that he was about to be dismissed, as he acknowledged at the plenum:

64. For an excellent analysis of the Zhukov affair written long before the archives were opened, see Timothy J. Colton, Commissars, commanders, and civilian authority: The structure of Soviet military politics (Cambridge, MA: Harvard University Press, 1979): 175-195. Colton's account holds up very well in the light of the new evidence. 
"Some three weeks ago, when I was instructed to set off for Yugoslavia and Albania, I said goodbye to all the members of the CC [Presidium], or at least to most of them, and we spoke as though we were the closest of friends. No one said a word to me about any problem. [...] I was not given the slightest hint that my behavior was somehow deemed improper. Only now are they saying this to me. [...] We all parted in such good spirits and warm friendship three weeks ago that it's still hard to believe all this has suddenly happened."65

In a remarkably short period of time after Zhukov's departure, Khrushchev arranged with the other Presidium members (and with senior military officers) to deprive the defense minister of all his top posts. The CPSU Presidium formally endorsed the ouster of Zhukov and the appointment of a successor, Marshal Rodion Malinovskii, at a meeting on 26 October, which Zhukov was hastily summoned to attend while he was still in Albania. The announcement of his dismissal and the appointment of Malinovskii as defense minister was carried by the TASS news agency later that day. Only after Zhukov's fate was sealed did Khrushchev convene the Central Committee.

Because the notes from Khrushchev's earlier discussions and from the relevant Presidium meetings (especially the meetings on 19 and 26 October) have not yet been released, key information about Khrushchev's motives in the affair is still unavailable. ${ }^{66}$ The plenum documents show only what Khrushchev wanted the Central Committee to hear, not necessarily what he really believed. Nevertheless, the plenum materials do add some intriguing details to previous accounts and, if used circumspectly, shed considerable light on the reasons for Khrushchev's move against his erstwhile ally.

One of the most valuable aspects of the declassified documents, repetitive and turgid though they may be, is that they clarify the allegations against Zhukov. The general case against Zhukov had been known since a few days after the plenum, when summary materials were published in the CPSU daily Pravda. ${ }^{67}$ Official histories of the Soviet Army's political organs, published in 1964 and 1968, had provided some additional information. ${ }^{68}$ Even so, a few of the allegations were at best unclear, and in some cases it was not known precisely what Zhukov had been

65. "Plenum TsK KPSS, 28-29 oktiabria 1957 g., XX Sozyv: Stenogramma vtorogo zasedaniia," 27-29 October 1957 (Strictly Secret), TsKhSD, f. 2, op. 1, d. 266, 1. 57.

66. One item that has been released in the materials gathered for the plenum, a letter from the Soviet minister of culture, Nikolai Mikhailov, to the CPSU Presidium, indicates that Zhukov's ouster was assured as of 25 October, the day before the CPSU Presidium formally approved the measure. See "V Prezidium TsK KPSS," 25 October 1957 (Secret), from N. Mikhailov, TsKhSD, f. 2, op. 1, d. 261, 1l. 45-51. No doubt, other documents, not yet released, will shed greater light on the timing and motives of Khrushchev's actions.

67. "Informatsionnoe soobshchenie o Plenume Tsentral'nogo Komiteta KPSS" and "Postanovlenie Plenuma TsK KPSS ob uluchshenii partiino-politicheskoi raboty v Sovetskoi Armii I Flote," Pravda, (November 3, 1957): 1-3.

68. Iu. P. Petrov, Partiinoe stroitel'stvo v Sovetskoi Armii i Flote (1918-1961) (Moscow: Voenizdat, 1964): 460-462; and Iu. P. Petrov, Stroitel'stvo politorganov, partiinykh $i$ komsomol'skikh organizatsii Armii i Flota (1918-1968) (Moscow: Voenizdat, 1968): 434-439. 
accused of. Nor was it known whether Zhukov had tried to defend himself against the charges. The vast quantity of declassified testimony and supporting documentation introduced at the plenum, beginning with Suslov's opening speech (which outlined all of Zhukov's alleged transgressions), gives a much better sense of what the charges entailed.

For example, it had long been known that Zhukov was denounced for having proposed certain changes in high-level military organs, but it was not known precisely what his alleged intentions were. The plenum materials indicate that Zhukov was accused of having wanted to abolish the Higher Military Council, a body consisting of all the members and candidate members of the CPSU Presidium as well as all the commanders of military districts, groups of forces, and naval fleets. The Higher Military Council was under the direct jurisdiction of the Defense Council, the supreme command organ in the USSR, whose existence had not yet been publicly disclosed. According to Suslov's speech at the plenum, Zhukov had refrained from convening the Higher Military Council and had then proposed to disband it. The CPSU Presidium, Suslov added, "rejected the defense minister's unwise proposal." 69

The plenum materials also clarify what Zhukov allegedly wanted to do with the extensive system of Military Councils. Each military district, group of forces, and naval fleet had its own Military Council, which consisted of regional party secretaries as well as senior commanders and political officers from the local military units. The Military Council was responsible for "upholding the constant combat and mobilization readiness of troops, the high quality of combat and political training, and the strictness of military discipline." 70 According to Suslov, Zhukov wanted to "transform the Military Councils into informal consultative organs under the [military] commanders," a step that supposedly would have relegated the Communist party to a subordinate role in military affairs:

"It didn't bother Cde. Zhukov that the members of the Military Councils in the [military] districts include secretaries of the party's oblast' and territorial committees and secretaries of the Central Committees of the union-republic Communist parties. It was perfectly fine with him that the secretaries of oblast' committees, territorial committees, and Communist party CCs would be placed "under the commanders and not given an equal voice' in the Military Councils."'71

Suslov emphasized that "the existence of full-fledged Military Councils in no way detracts from the dignity and role of [military] commanders. On the contrary, the

69. "Doklad tov. Suslova M. A.: Ob uluchshenii partiino-politicheskoi raboty v Sovetskoi Armii i Flote," 28 October 1957 (Strictly Secret), in "Plenum TsK KPSS 28-29 oktiabria 1957 g., XX Sozyv: Stenogramma pervogo zasedaniia (utrennego)," 27-29 October 1957 (Strictly Secret), TsKhSD, f. 2, op. 1, d. 266, 1.14 (hereafter: "Doklad tov. Suslova M. A.").

70. Marshal S. F. Akhromeev, et al., eds., Voennyi entsiklopedicheskii slovar', 2nd ed. (Moscow: Voenizdat, 1986): 146.

71. “Doklad tov. Suslova M. A.," 11. 15-16. 
Military Councils allow the commanders to be certain that the decisions they make are appropriate." 72 Only a "petty tyrant," Suslov added, would have tried to scale back the Military Councils.

Another allegation discussed at great length at the plenum was Zhukov's supposed desire to establish a "cult of personality" around himself. One of the main things cited as evidence for this accusation was the efforts that Zhukov allegedly made to highlight the depiction of his own feats in the film "Velikaia bitva" ("The Great Battle"), a documentary about the Battle of Stalingrad. The film had been commissioned in October 1953 to replace the 1943 film "Stalingrad," which was deemed to give undue prominence to Stalin's role in the campaign. The new documentary was completed in early 1957 but was then subject to a number of revisions. At the CPSU Presidium meeting on 26 October, Zhukov insisted that he had not been involved in the production of "Velikaia bitva," but Suslov argued at the plenum that Zhukov's denials "do not correspond to reality." 73 Relying on a letter from the Soviet minister of culture, Nikolai Mikhailov, which was drafted at Khrushchev's request after the decision to remove Zhukov had been made, Suslov claimed that the defense minister had "directly and actively intervened in the filmmaking" numerous times to "propagandize [his own] cult of personality." " Suslov cited a few other items as well — notably, the preparation of an article about World War II for the Great Soviet Encyclopedia, and the majestic depiction of Zhukov in a painting in the Soviet Army Museum — to bolster his claim that "Zhukov was deeply concerned to aggrandize his persona and his prestige, without regard for the interests of the [Communist] Party." Having waged "a struggle against the well-known abuses resulting from I. V. Stalin's cult of personality," Suslov declared, "our Party must never again permit anyone to build up a cult of personality in any form whatsoever." 75

Perhaps the most serious allegation put forth by Suslov and Khrushchev was that Zhukov had been trying to "take control of the army away from the party and to establish a one-man dictatorship in the armed forces." $76 \mathrm{Khrushchev}$ argued that there was supposed to be "a division of responsibilities among [senior] members of the party," and that no single official, not even the CPSU First Secretary (much less the defense minister), could "take on all the functions of the Central Committee." $77 \mathrm{He}$ condemned Zhukov for allegedly having sought to "place everything, the Committee on State Security as well as the Ministry of Internal Affairs, under the Ministry of

72. Ibid., 1. 16 .

73. Ibid., 1. 21.

74. Ibid. For the letter from Mikhailov, see "V Prezidium TsK KPSS," as cited in Note 66 supra. When evaluating Mikhailov's letter, it is important to bear in mind that the letter was not written spontaneously. Mikhailov had been instructed by Khrushchev to write such a letter, and his detailed assertions must be judged accordingly.

75. "Doklad tov. Suslova M. A.," 11. 4, 17-18.

76. "Materialy k Protokolu No. 5 zasedaniia Plenuma TsK KPSS 28-29. 10. 1957 g.," TsKhSD, f. 2, op. 1, d. 261, 1. 72 .

77. "Rech' tov. N. S. Khrushcheva," 11. 60-61. This passage in the verbatim transcript was deleted from the stenographic account. 
Defense." Khrushchev added that if the situation had continued this way "for another month or so," Zhukov would have been insisting that "the Central Committee, too, must be brought under the jurisdiction of the Ministry of Defense."78

Khrushchev produced no concrete evidence to substantiate these claims, but both he and Suslov specifically accused Zhukov of having sought to establish military jurisdiction over the main security organs:

"Cde. Zhukov recently proposed that the chairman of the Committee on State Security and the Minister of Internal Affairs be replaced by military officers. What lay behind this suggestion? Wasn't it an attempt to fill the leading posts in these organs with his own people, with cadres who would be personally beholden to him? Isn't he seeking to establish his own control over the Committee on State Security and the Ministry of Internal Affairs?"79

Newly available evidence suggests that this charge was disingenuous, or at least highly misleading. The KGB's own top-secret history of its activities and organization, compiled in 1977, makes no mention of any such effort by Zhukov. On the contrary, the KGB textbook emphasizes that in the mid- and late 1950s "the CPSU Central Committee and the Soviet government" themselves sought to "fill the ranks of the state security organs with experienced party and military personnel" in order to "eliminate the consequences of the hostile activity of Beria and his accomplices." 80 To the extent that military officers were brought into the KGB and MVD after 1953, this trend was initiated and encouraged by the top political leadership. (Khrushchev and his colleagues, after all, had learned at the time of Beria's arrest that they could count on Zhukov and other senior military officers to support the CPSU.)

The spuriousness of this particular accusation reflected a more general pattern. As valuable as the plenum materials are in spelling out the case against Zhukov, the main conclusion one can draw from the documents is that the affair was little more than a personal clash between Khrushchev and Zhukov. Despite the sinister veneer that Khrushchev gave (both at the plenum and later on in his memoirs) to Zhukov's actions, the documents leave no doubt that the charges against Zhukov were largely contrived. Zhukov was justified in pointing this out during his first speech at the plenum: "I think we have gathered here not to review individual offenses. [...] That's not what this is all about. In the end, the question here is political, not juridical." 81

78. Ibid., 1. 61 .

79. "Doklad tov. Suslova M. A.,"1. 21.

80. Lieut.-General V. M. Chebrikov et al., eds, Istoriia sovetskikh organov gosudarstvennoi bezopasnosti, No. 12179, Top Secret (Moscow: Vysshaia Krasnoznamennaia Shkola Komiteta Gosudarstvennoi Bezopasnosti, 1977): 532 (emphasis added). This lengthy textbook is still classified in Moscow, but a copy was unearthed in Riga by the Latvian scholar, Indulis Zalite, who is now head of the Center for Documentation of the Consequences of Totalitarianism, a leading research institute in Riga. He generously allowed me to photocopy it and many other Soviet KGB documents that are currently inaccessible in Moscow.

81. "Plenum TsK KPSS, oktiabr' 1957 goda: Stenogramma tret'ego zasedaniia (utrennego)," TsKhSD, f. 2, op. 1, d. 266, 1. 60. 
Khrushchev's motive in convening the Central Committee was similar to his (and others') motives in orchestrating the July 1953 plenum to denounce Beria. Rather than acknowledge that the ouster of Zhukov was the latest stage in a consolidation of power, Khrushchev used the October 1957 plenum to suggest that the defense minister had been removed because of genuine concerns about the Communist Party's supervision of the army.

It is true, of course, that numerous problems existed in the Soviet armed forces in 1957, and that the military's political organs were not functioning as well as most officials had hoped. It is also true that Zhukov wanted to enforce stricter discipline in the army by establishing a more orderly chain of command and by mitigating the opportunities for insubordination. And it is true that Zhukov tended to be impatient and abrasive with his colleagues and subordinates (both fellow soldiers and party officials), and that he went along with efforts to play up his own role in World War II. Nevertheless, these deficiencies hardly amounted to a broad indictment of Zhukov's tenure as defense minister. The activities that Suslov claimed were an attempt by Zhukov to establish a "cult of personality" were not at all unusual in the context of Soviet politics. The routine glorification of Khrushchev in the late 1950s far exceeded anything that Zhukov may have been promoting for himself. Similarly, most of the other problems that were highlighted at the plenum, both in the armed forces as a whole and in the political organs, had long existed. Zhukov may have marginally worsened a few of these problems, but he also seems to have rectified certain key deficiencies, notably by boosting morale and increasing the combat readiness of frontline units. During the one major operation that Zhukov oversaw as defense minister, the large-scale intervention in Hungary in November 1956, Soviet troops accomplished their mission within a few days despite encountering vigorous armed resistance from Hungarian insurgents.

The flimsiness of the allegations against Zhukov undoubtedly accounts for Khrushchev's decision to raise questions about Zhukov's military abilities and accomplishments. Although Khrushchev and Suslov both claimed that they "deeply value Cde. Zhukov's performance during the Great Patriotic War," they also wanted to ensure that Zhukov's legendary reputation and stature would not cause members of the Central Committee to be hesitant about criticizing him. To this end, Khrushchev downplayed Zhukov's role in World War II by arguing that Vasilii Chuikov, not Zhukov, was the "chief hero" of the Stalingrad campaign. Khrushchev also rebuked Zhukov for dwelling solely on the positive aspects of his military career:

“Cde. Zhukov, I don't want to disparage your military accomplishments, but you should think about it a bit. You had both your successes and your failures, just as all the other generals and marshals did. Why do you insist on talking only about the successes and victories, and completely glossing over the failures?"82

82. "Rech' tov. N. S. Khrushcheva,"1. 45. 
Amplifying on this point later on, Khrushchev declared that "our [other] generals and marshals know at least as much as Zhukov does, and perhaps much more, about military organization and the other military sciences. Cde. Zhukov has only a poor understanding of the latest technology." 83

In addition to expressing doubts about Zhukov's military prowess, Khrushchev alleged that Zhukov had advocated certain foreign policy steps that "bordered on treason." In particular, Khrushchev claimed that Zhukov "wrote a memorandum to the party's Central Committee recommending that we accept [the U.S. government's] 'Open Skies' proposal," which would have entitled the United States and the Soviet Union to fly reconnaissance flights over one another's territory to monitor compliance with nuclear disarmament agreements. Khrushchev averred that the other members of the Presidium were startled to learn that "the defense minister, of all people, could have favored such a thing," and they "reacted with heated protests against Zhukov's proposal." 84 Khrushchev's efforts to impugn Zhukov's "adventurist" positions on "the most important foreign policy issues facing the Soviet Union" (in the phrasing of the plenum resolution) were not altogether different from the attempts in July 1953 to portray Beria's alleged views about Germany in the most unsavory light possible.

Despite the many similarities between the October 1957 plenum and the July 1953 plenum, there was one fundamental difference. Unlike Beria, who was held in prison during the July 1953 sessions and executed five months later, Zhukov was given the opportunity to speak twice at the October 1957 plenum and to interject comments from time to time during others' remarks. His first speech came after the main allegations against him had been laid out, and his second, much briefer (and more contrite) statement came just before Khrushchev's lengthy speech at the fourth session of the plenum, on the evening of 29 October. On neither occasion did Zhukov project an air of angry defiance or even take as firm a stand as Molotov did in July 1955, but he defended his record at some length and rebutted the most lurid accusations against him. Overall, he left no doubt that he strongly disagreed with the grounds for his dismissal. At the same time, Zhukov had decided beforehand that it would be best if he accepted responsibility for certain "mistakes" (whether real or not) and indicated his willingness to comply with the party's wishes:

"I request that you understand that [my] mistakes were not the result of any sort of deviation from the line of the party, but were the sorts of mistakes that any working official might make. I assure you, comrades (and I think I will receive appropriate support in this regard), that with the help of our party I will be able, with honor and dignity, to overcome the mistakes I have committed, and I absolutely will be a worthy figure in our party. I was and always will be a reliable member of the party." 85

83. Ibid., 1. 65. This passage in the verbatim transcript was toned down in the final stenographic account.

84. Ibid., 11. 58-59.

85. "Plenum TsK KPSS, 28-29 oktiabria 1957 g., XX Sozyv: Stenogramma vtorogo zasedaniia," 27-29 October 1957 (Strictly Secret), TsKhSD, f. 2, op. 1, d. 266, 1. 76. 
Zhukov's willingness to acknowledge unspecified shortcomings reinforced the longstanding pattern of civil-military relations in the Soviet Union. If the most renowned figure in the Soviet armed forces was willing to submit himself to the discipline of the Communist Party, the norm of civilian supremacy was clearer than ever.

This is not to suggest, however, that the affair was in any way an institutional clash between the party and the military. On the contrary, the declassified plenum materials show, more strongly than ever, that the Zhukov affair was not a confrontation between civilian officials and military commanders. During the plenum, senior military officers went out of their way to emphasize that Khrushchev "is not only First Secretary of the CPSU Central Committee, but is also chairman of the Defense Council," a position equivalent to commander-in-chief of the Soviet armed forces. ${ }^{86}$ Although it is now clear that General A. S. Zheltov, the chief political officer in the Soviet Army in 1957, was instrumental in pressing for Zhukov's ouster, a substantial number of career military officers were also behind the move. (The plenum documents suggest that Zheltov resented Zhukov mainly because Zheltov had been left off the Central Committee at the XX Party Congress in 1956, an omission that Zheltov evidently blamed on Zhukov. ${ }^{87}$ ) Zheltov's report at the CPSU Presidium meeting on 19 October was a catalyst for the final actions to remove Zhukov, but it is clear that the preliminary maneuvering had begun well before then, with the involvement of senior military commanders. Khrushchev was able to secure a political-military consensus on the need to dismiss Zhukov.

The lack of any civilian-military disagreements on this issue is well illustrated by the plenum itself, where not a single military officer spoke in defense of Zhukov. The norm of subordination to party control outweighed any inclination that senior commanders might have had to speak even mildly in favor of the deposed minister. ${ }^{88}$ All of Zhukov's military colleagues and subordinates joined with Khrushchev and Suslov in denouncing Zhukov's alleged efforts to foster a "cult of personality" and to "take control of the army away from the party." Zhukov's successor, Malinovskii, expressed regret that Zhukov had allowed problems in the military to become so acute that the Central Committee was forced to step in to resolve matters:

"Comrades, we military officers are very glad that the Plenum of the Central Committee is discussing the matter of strengthening party-political work in the Soviet Army and Navy. On the other hand, it is regrettable that we, as military officers and members of the party, have reached the point where the Central Committee itself has been compelled to intervene in this matter." 89

86. "Plenum TsK KPSS, oktiabr' 1957 goda, XX Sozyv: Stenogramma tret'ego zasedaniia Plenuma TsK KPSS, 28-29.10.1957 g.,” TsKhSD, f. 2, op. 1, d. 268, 1. 77.

87. See the comments to this effect in "Rech' tov. N. S. Khrushcheva," 11. 5-6.

88. Malinovskii, who had been a first deputy minister during Zhukov's tenure, started his remarks with a positive observation (saying that "he had no ill feelings toward Cde. Zhukov" and had "always gotten along well" with him), but then offered a highly critical assessment. "Plenum TsK KPSS, oktiabr' 1957 goda, XX Sozyv: Stenogramma vtorogo zasedaniia Plenuma TsK KPSS,”28 October 1957 (Strictly Secret), TsKhSD, f. 2, op. 1, d. 267, 1l. 63-64.

89. Ibid., 1. 64. 
Even military officers who had benefited greatly during Zhukov's tenure, such as Fleet Admiral Sergei Gorshkov, who had been appointed commander-in-chief of the Soviet navy in 1956, argued that Zhukov's "leadership of the ministry has created an extremely agonizing, oppressive, and distasteful situation, which is totally at odds with party and Leninist principles of leadership." Gorshkov insisted that Zhukov "regards himself as absolutely infallible" and "refuses to tolerate views different from his own, often reacting with uncontrolled rage, invective, and abuse." 90 Other officers expressed even stronger criticism, doing their best to side completely with the party hierarchy.

So clear was the party's dominance of the military that even the officers who had known Zhukov the longest - Marshal Semyon Budennyi, Marshal Ivan Konev, and Marshal Sergei Biriuzov, among others — disavowed their past ties with him. ${ }^{91}$ After one of the speakers on the first day of the plenum referred to the "special friendship between Cde. Konev and Marshal Zhukov," Konev spoke with Khrushchev and sent a note to the CPSU Presidium insisting that it would be a "profound mistake to believe I was ever particularly close to Zhukov." Konev's denials prompted Khrushchev to begin his own speech at the plenum by "correcting the record" along the lines that Konev sought:

"We don't have any basis for suggesting that Cde. Konev's past relationship with Cde. Zhukov should cast any sort of pall on Cde. Konev. Cde. Konev is a member of the CPSU CC and a long-time member of the party, and he always was a loyal member of the party and a worthy member of the CPSU CC. He remains so now." 92

By highlighting Konev's eagerness to renounce his previous ties with Zhukov, Khrushchev underscored the consensus against the deposed minister and let the full Central Committee see that, despite Zhukov's misdeeds, high-ranking military officers were no different from other "true Communists" in placing party loyalty above personal relationships.

One final point worth mentioning about the October 1957 plenum is the valuable light it sheds on the state of the Soviet armed forces in the mid- to late 1950s. Intriguing information about this matter can be found not only in the proceedings, but in the collection of documents associated with the plenum. These documents consist mainly of various drafts of the plenum resolution and the "closed letter" that was eventually distributed to all CPSU members about the Zhukov affair. ${ }^{93}$ The letter itself adds nothing to the many charges outlined at the plenum, but one of the other documents released to the Central Committee, a top-secret "Order of the

90. 'Plenum TsK KPSS, oktiabr' 1957 goda, XX Sozyv: Stenogramma pervogo zasedaniia Plenuma TsK KPSS,” 28 October 1957 (Strictly Secret), TsKhSD, f. 2, op. 1, d. 266, 11. 123124.

91. See, for example, the speeches recorded in TsKhSD, f. 2, op. 1, d. 267, 268, and 269.

92. “Rech' tov. N. S. Khrushcheva,” 11. 4-5. 
USSR Minister of Defense," signed by Zhukov and the chief of the Soviet General Staff, Marshal Vasilii Sokolovskii, on 12 May 1956, provides an interesting assessment of "the state of military discipline in the Soviet Army and Navy" in the mid-1950s. ${ }^{94}$ Zhukov and Sokolovskii highlighted problems in the Soviet armed forces that seem remarkably similar to many of the ills afflicting today's Russian armed forces:

\begin{abstract}
"Both the army and the navy are plagued by a huge number of crimes and extraordinary incidents, of which the most serious dangers are posed by: cases of insubordination to commanders and, what is particularly unacceptable in the army, the voicing of insults to superiors; outrageous behavior by servicemen vis-a-vis the local population; desertion and unexplained leaves of absence by servicemen; and accidents and disasters with aviation transport, combat aircraft, and ships.

The problem of drunkenness among servicemen, including officers, has taken on vast dimensions in the army and navy. As a rule, the majority of extraordinary incidents and crimes committed by servicemen are connected with drunkenness.

The extremely unsatisfactory state of military discipline in many units and formations of the army, and especially in the navy, prevents troops from being maintained at a high level of combat readiness and undermines efforts to strengthen the Armed Forces." 95
\end{abstract}

The standards used by Zhukov and Sokolovskii may have been a good deal higher than those used today, and the pervasiveness of "unsavory phenomena" is undoubtedly greater now than it was then. Some of these problems had been known earlier from the testimony of emigres/defectors and occasional articles in the Soviet press. ${ }^{96}$ Nevertheless, it is striking (and comforting) to see that dissatisfaction about the state of military discipline was nearly as great in Moscow some 40-45 years ago as it is today.

93. "Materialy k Protokolu No. 5 zasedaniia Plenuma TsK KPSS 28-29. 10. 1957 g.," TsKhSD, f. 2, op. 1, d. 261. The drafts of the closed letter, "Zakrytoe pis'mo Tsentral'nogo Komiteta KPSS ko vsem partiinym organizatsiiam predpriiatii, kolkhozov, uchrezhdenii, partiinym organizatsiiam Sovetskoi Armii i Flota, k chlenam i kandidatam v chleny Kommunisticheskoi partii Sovetskogo Soiuza," are found on 11. 99-122ob.

94. "Prikaz Ministra oborony SSSR No. 0090, 12 maia 1956 g., o sostoianii voinskoi distsipliny v Sovetskoi Armii i Voenno-Morskom Flote i merakh po ee ukrepleniiu," 12 May 1956 (Top Secret), signed by G. Zhukov and V. Sokolovskii, TsKhSD, f. 2, op. 1, d. 261, 11. 3135.

95. Ibid., 1. 32.

96. Herbert Goldhamer, The Soviet soldier: Soviet military management at the troop level (New York: Crane, Russak \& Company, 1975): 141-169. 


\section{Concluding observations}

This overview of the structure, context, and content of declassified materials from Central Committee plenums shows both the limitations and the potential value of these documents. So long as scholars bear in mind that the Central Committee was not a decision-making body and that the plenums were carefully managed by top CPSU officials for their own purposes, the documents can yield a good deal of useful information. Some of the materials provide fresh insights into key trends and events, including domestic changes in the Soviet Union and important episodes from the Cold War. Other documents are important mainly because of what they reveal about the manipulation of the plenums by senior officials. One of the most salient features of the plenums during the first five years after Stalin's death was the spillover from the leadership struggle. Even when the plenums were supposed to focus on crucial domestic or foreign issues, the divisions among top leaders had a far-reaching effect on the proceedings. By the late 1950s, after Khrushchev had dislodged his major rivals and consolidated his position as CPSU First Secretary, the plenums increasingly were devoted to the growing rift between the Soviet Union and China. This theme continued even after Khrushchev was unexpectedly removed in 1964.

The plenum materials cover only selected portions of Soviet history and Soviet foreign policy. Many topics were barely considered at all by the Central Committee. The plenum documents are no substitute for the vastly more important and far more voluminous records of the supreme decision-making body in the Soviet Union, the CPSU Presidium/Politbiuro. Those records, unfortunately, are still largely sealed. Yet even if the Politbiuro archives are eventually made fully accessible, the plenum materials will remain a valuable, indeed indispensable, source. Although the plenum transcripts and supplementary documents must be used with great caution, they provide a wealth of insights into the role of the Central Committee in Soviet policy-making.

Harvard University

Davis Center for Russian Studies

1737 Cambridge Street

Cambridge MA 02138

e-mail:mkramer@fas.harvard.edu 